\title{
Yeltsin's ecology adviser chips away at a sorry past
}

\begin{abstract}
Washington. Alexei Yablokov knows that he's pushing a stone uphill as counsellor to the Russian president, Boris Yeltsin, for ecology and public health. A zoologist by training and the former director of the Institute of Developmental Biology in Moscow, Yablokov now spends a good deal of his time uncovering new evidence of the catastrophic environmental legacy of the former Soviet government. But he knows that economic considerations are paramount, and that his message must be tempered by harsh fiscal realities.
\end{abstract}

A case in point is the recent decision to continue operating a family of Russian nuclear reactors of the Chernobyl type on the grounds that the country's need for electric power outweighs the dangers posed by the graphite RBMK reactors. Yablokov believes that the country would be better off if it abandoned nuclear power and switched to gas turbines, a move made easier by his estimate that Russia will reduce its energy consumption by 30 per cent in converting from a military to a civilian economy. But his views failed to carry the day at a recent cabinet meeting. "Only the minister of the environment and public health supported me", he says. "All the other ministers are against me for economic reasons."

Yablokov left his laboratory in 1989 for politics because of the opportunity to influence the country's environmental policies, and he does not regret his decision. "As counselor to the president I help to arrange his schedule, influencing where he goes and what he does", he says.

Last month, Yablokov arranged for Yeltsin to visit the Volga River, where he signed an order protecting the sturgeon, whose well-being is a source of national pride. And earlier this year, Yeltsin proposed legislation to add an environmental component to efforts to redefine national security following the end of the Cold War. In both cases, Yablokov used his position as resident expert to strengthen Yeltsin's policies on environmental preservation. Yablokov also successfully appealed against a decision to build a dam on the Katun River in eastern Siberia, persuading Yeltin to delay the project pending further study of its effect on the environment.

Environmentalists elsewhere applaud his work. "He has been very influential in shaping government decision-making in Russia on environmental issues", says Ronald Kendall of Clemson University and president of the 3,000-member Society of Environmental Toxicology and Chemistry, which gave Yablokov its first-ever science award during its annual convention last week in Cincinnati, Ohio. "He's kept the public and the president aware of past, present and future environmental problems from radioactivity to DDT", says Murray Feshbach of Georgetown University, a demographer and longtime Kremlinologist.

Although Yablokov does not direct a large bureaucracy and has fewer than a dozen people on his personal staff, Kendall says that he is influential in redirecting

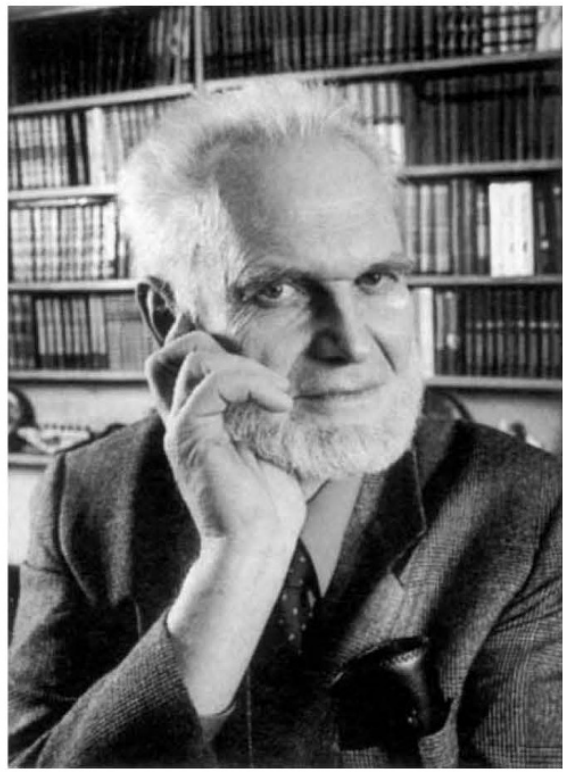

Yablokov has president's ear.

funding among ministries. Yablokov has also acted as host to the US vice presidentelect, Al Gore, during a visit as a US senator, and he can be expected to exploit that relationship as Russia searches for ways to finance costly cleanups.

Apart from the economy, Yablokov must also contend with a paucity of useful data. Speaking last week at the US Armed Forces Radiobiology Research Institute in Washington, Yablokov shook his head at a question about followup studies on those affected by past environmental disasters. "Whenever we analyse past data, we have to realize that we have no right to believe it", he replied. "It was collected for political purposes, and often it does not tell us what we need to know."

Jeffrey Mervis

\section{Russian academy institutes told to set priorities}

Moscow. The Russian Academy of Sciences is losing control over all but its weakest institutes as its entire research structure adapts to the need for greater self-sufficiency.

The various branches of the academy have been ordered to rank their research programmes since the ruling presidium decided last month to sharply reduce its portfolio. Those not seen as priorities will be expected to find other sources of support or will be forced to close. The abolition of entire institutes is another possibility.

The presidium's action is not expected to affect institutes that have spent the past two years preparing to stand on their own, in particular the institutes of general physics, molecular genetics and molecular biology. The director of the Institute of Chemical Physics, Vitaly Goldansky, expects no reduction in the size of his staff, while the Institute of General Physics regards a decision to reduce its staff by 10 per cent as simply a pruning of those who have been the least productive. Other institutes expect to supplement their reduced state subsidy by leasing part of their buildings to commercial enterprises or by obtaining grants from international organizations.

A new trade union of employees has criticized the presidium's actions and disputes its estimate that the academy faces a budget deficit of more than 1 billion rubles. It argues that self-sufficiency should not be the sole factor in deciding what research to support and that the differing costs of infrastructure must also be considered. "A rigid selection of priorities at the expense of all else will result in a system in which only the strongest survive", says Vitaly Sobolev, chairman of the trade union, which has asked the presidium to reconsider.

A greater threat to many institutes is the delay in implementing an emergency measure that would make it easier for researchers to benefit from outside support. The measure, signed in February by the Russian president, Boris Yeltsin, would give scientists the right to open accounts in foreign banks and exempt from taxes of as much as 40 per cent purchases of equipment and sums of hard currency. It would also prohibit the state from dictating the ways in which an outside grant could be used.

"I am afraid that it will remain a draft forever", says Igor Nikolayev of the Ministry of Science. "I don't see any other way out than to call on the scientists themselves to lobby this document at any level of power accessible to them." Without such changes, Russian researchers may have little to gain from efforts by Western and European countries to shore up their laboratories.

Vladimir Pokrowsky 